\title{
Fear and Love in film The Loop by Wojciech Jerzy Has*
}

\author{
Iwona Grodź \\ Adam Mickiewicz University, Poznan, Poland
}

\begin{abstract}
The topic of the paper is The Loop (Pętla, 1956), the first feature film by Wojciech Jerzy Has, a well-known director from the so-called "Polish film school". The film is based on a story by Marek Hłasko, the author of an internationally known collection of stories A Pretty Girl and a novel Owl, the Baker's Daughter. The Loop is a story of Kuba, an alcoholic who is making his last attempt to get over his addiction. The viewers see one day of his life. In Has's adaptation the main protagonist is not simply a drunk, he is someone who cannot come to terms with the new reality —in the world of appearances, falsehood, during the so-called "small stabilisation". Thoroughly analysed will be Kuba's romantic relations with two women: a former love and his present fiancée who is trying to liberate him not only from the world, but primarily from himself. Love and fear are the two feelings that characterise the emotional state of the film's main protagonist. Important will also be the perception of The Loop's protagonist as everyman, i.e., someone who could be everybody and nobody at the same time; someone who wishes to finally break up with the past, but is too tightly attached to it. His relations with a group of former friends, his relationship with the city prevent him from escaping. Can love come to the rescue? Will fear be the driving force for change? I will try to answer these and other questions in my paper.
\end{abstract}

Keywords: history of Polish film, Wojciech Jerzy Has, fear and love in film

\section{Introduction}

"The passage of time and the premonition of catastrophe, some unspecified fatalism and the feeling of besetment. This very much corresponded to how I saw and felt things"1 — said Wojciech Has. That is why Pętla (The Noose/The Loop) by Marek Hłasko was for him perfect material for a feature film debut. Additionally - in the director's opinion - the prose by the author of Cmentarze (Cemeteries) was exceptionally "photogenic". ${ }^{2}$ The last word of this statement seems to be particularly meaningful in the context of the film in question. It is not in the least only about identifying its meaning with visual beauty (in the colloquial language there are expressions: photogenic actor, landscape, object, etc.), which is relative, but rather with a fairly enigmatic concept from the field of photography and film theory.

\section{Late Debut}

In its film version The Noose is not only a story about alcoholism. The creator of Pożegnania (Farewells)

\footnotetext{
${ }^{*}$ Text translated Iwona Mazur and Iwona Grodź.

Iwona Grodź, lecturer, doctor, Faculty of Polish and Classical Philology (Institute of Polish Philology, Department of Film, Television and New Media), Adam Mickiewicz University. See http://www.filmoznawstwo.com/en/dr-iwona-grodz (access 24 X 2015).

${ }^{1}$ W. Has, Nie lubie niespodzianek na planie (I don't like surprises on the set). An interview by M. Kornatowska. In Debiuty polskiego kina (Debuts in the Polish cinema), M. Hendrykowski (Ed.), Konin 1998, p. 64.

${ }^{2}$ Ibidem, p. 64.
} 
was rather concerned with making a film about loneliness and being "trapped" in one's fate. In the filmic world there is, in accordance with the author's intention, condensation of time and space (the beginning of the film is a projection of its end). ${ }^{3}$ The action takes place within 24 hours. Such a "state of concentration" required therefore better organization in terms of motifs that determine the psychological condition of the protagonist. That is why in The Noose nothing is accidental, everything is linked to a motif: of time and premonition of imminent death. Therefore, although the director filled the entire reality suggested by the writer with concrete matter, already at that stage he made a number of changes.

In his writing, Marek Hłasko was a realist and a careful observer. On the other hand he knew the elusive world of human emotions. ${ }^{4}$ The writer believed that "literature should not transmit a reliable image of the reality, but an author's visions or worldview, as it is the author who is the medium of the world". 5 Nonetheless, his short stories in the first place perfectly imitated the reality. ${ }^{6}$ The identification mark of this prose is also pessimism, "black as a guarantee of authenticity" ${ }^{7}$ Hłasko’s writing is characterized by ambivalence of values. The evil was mitigated by the good; the good was obstructed by the evil. Additionally, the writer was fascinated with ugliness, and thus he showed naturalistic and expressionistic tendencies. ${ }^{8}$ This is corroborated by the opinions of some critics who describe Hłasko's stories as "rapacious". Janusz Skwara, on the other hand, when writing about a "black film", which refers to romanticism and expressionism, noted that it is close to the writer's style. $^{10}$

It should also be mentioned that some critics, pointing to Has's The Noose's link with expressionism, made a direct reference to Marek Hłasko's story. For example, Rafał Marszałek wrote that "not only the film, but also - if not primarily — its literary original, are expressionistic in nature". ${ }^{11}$ By saying so, he suggests that this style of visual realization was in a way "written" into the adapted work. On the other hand, it must be emphasized that the story by the author of Cemeteries is mainly based on dialogues. All descriptions of the apartment or the city were significantly reduced there. ${ }^{12}$ Has, his set designer Roman Wołyniec and costume designer Andrzej Cybulski had to create this "peculiarly photogenic" world themselves.

Stories by Marek Hłasko have tended to be considered as "filmic", which is proven by the easiness of their translation into film language. In the case of The Noose, this "easiness" consisted in a very slight interference

\footnotetext{
${ }^{3}$ Cf. S. Kuśmierczyk, Wstęa Möbiusa jako czasoprzestrzeń dzieła filmowego. Na przykładzie "Pętli” Wojciecha Hasa $i$ "Zabicia ciotki" Grzegorza Królikiewicza (The Möbius strip as the space-time of a filmic work. On the example of "The Noose" by Wojciech Has and "The Killing of the Aunt" by Grzegorz Królikiewicz), "Kwartalnik Filmowy" 2000, no. 29/30, pp. 20-30.

${ }^{4}$ Cf. J. Roszko, Cudowna podróż po rynsztokach świata (An amazing journey to the gutters of the world), "Dziennik Polski" 1967, no. 167; K. Zaleski, Inferno sentymentalne (Sentimental inferno), "Teksty” 1974, vol. 2; S. Stabro, W bursztynowej kuli. O twórczości i legendzie Marka Hłaski (In an amber ball. On the work and legend of Marek Hłasko), "Odra” 1983, no. 12 and 1984, no. 1. J. Tomkowski, Marek Hłasko jako bajkopisarz (Marek Hłasko as a fabler). In Sporne postaci polskiej literatury wspótczesnej (Disputed figures in the contemporary Polish literature), A. Brodzkiej and L. Burskiej (Eds.), Warszawa 1995, pp. 7-16.

5 J. Galant, Bogart i inni... (Bogart and others...). In J. Galant, Marek Hłasko, Poznań 1996, p. 96.

${ }^{6}$ K. Ludwicki, Marek Hłasko-pozer czy outsider? (Marek Hłasko-poser or outsider?). In K. Ludwicki, Kino Marka Hłaski (The cinema of Marek Hłasko), Katowice-Warszawa 2004, p. 10.

7 Ibid, s. 11.

${ }^{8}$ Cf. P. Wasilewski, Śladami Marka Hłaski (In the footsteps of Marek Hłasko), Kraków 1994, p. 114; B. Michałek, Szkice o filmie polskim (Sketches on the Polish film), Warszawa 1960, pp.26-27.

9 See J. Jarzębski, Powieść jako autokreacja (A novel as self-creation), Kraków 1984, p. 276.

10 J. Skwara, Świat “czarnego filmu” (The world of "black film”), Warszawa 1977, p. 109.

11 R. Marszałek, Tubylec i misjonarze (A native and missionaries), "Kino" 1973, no. 3, pp. 23-24.

12 J. Pyszny, Przestrzeń (Space). In M. Hłasko, Pierwszy krok w chmurach. Nastęny do raju (The first step in the clouds. The next one to the paradise), compiled by J. Pyszny, Wrocław 1999, BN I 295, pp. XXIX-XXXV.
} 
by Has with the literary text. ${ }^{13}$ The only significant change, because of it being symptomatic for the director, was a different profession of the protagonist who in the film "became" an artist. What is more, the adaptation also lacks attachment to a particular reality that was typical for the writer. Bolesław Michałek wrote that in Has's debut there is no "biological impetus found in the short story, the cynicism and vulgarity". ${ }^{14}$ The critic also noted that in Hłasko's story one can detect "a kind of impudence". ${ }^{15}$ The film, on the other hand, is completely different, "soft", understated, elegant, and not that brutal. This "softening" or poeticizing of the film can also be attributed to the actor playing the main character, Gustaw Holoubek, who with his serene, or even monotonous, acting softened the picture. ${ }^{16}$ In Has's screen adaptation, there is little left from the writer's irony, which we notice already in The Noose's motto: "With a good woman—life does not hurt/from good food—the stomach does not ache/from a good drink - the head does not ache...." ${ }^{17}$ The pessimism of the filmic vision eliminates it almost in its entirety.

In reviews and analyses of this film critics expressed radically different opinions. Some admired it, others were critical, yet some others claimed that The Noose is a "step that is neither forward nor back". In the context of Has's debut, most often mentioned were the exceptional maturity of the director's technique; ${ }^{18}$ the literary character of the dialogues; ${ }^{19}$ set design peculiarities (e.g., turpist exterior boiling down to the symbolism of objects, ${ }^{20}$ artificiality of depicted reality ${ }^{21}$ ); pessimism and melancholy as if taken out of The Lost Weekend by Billy Wilder ${ }^{22}$ or existentialist writings, ${ }^{23}$ expressionism similar to the one from Zimowy zmierzch (Winter Twilight) by Stanisław Lenartowicz ${ }^{24}$ or films from the $1920 \mathrm{~s}^{25}$ or even hidden Freudism. ${ }^{26}$

However, it was a misunderstanding to ascribe to The Noose didactic functions, ${ }^{27}$ or to write only about its (un)faithfulness towards its literary original. ${ }^{28}$ When it comes to the former issue, it should be noted that the social significance of Hłasko's story was consciously omitted by Has. The director-as was usually the case - wanted to make an individual's experience more universal. As regards the issue of faithfulness towards the original, it is a topic that will reoccur in the case of this director. Therefore, it should be said already at this point that all adaptations by Has are in fact variations on literary themes. The creator of Farewells took from

\footnotetext{
${ }^{13}$ K. Ludwicki, Wstęp (Introduction). In K. Ludwicki, Kino Marka Hłaski (The cinema of Marek Hłasko), op. cit., p. 8.

14 B. Michałek, W pogoni za stylem (In pursuit of style), "Nowa Kultura" 1958, no. 6, p. 6.

15 Ibid., p. 6.

${ }^{16}$ Cf. B. Michałek, Szkic o filmie polskim (A sketch on the Polish film), op. cit., pp. 48-54; B. Michałek, W pogoni za stylem (In pursuit of style), op. cit., p. 6.

${ }_{17}$ M. Hłasko, Pętla (The Noose). In M. Hłasko, Pierwszy krok w chmurach. Nastęny do raju (The first step in the clouds. The next one to the paradise), compiled by J. Pyszny, op. cit., p. 178.

${ }_{18}$ K. Eberhardt, Pętla-świadomy wybór stylu (The Noose - a conscious choice of style). In K. Eberhardt, Wojciech Has, Warszawa 1967, pp. 8-14; B. Michałek, Nadzieje, niepokoje (Hopes and fears), "Teatr i Film” 1958, no. 4, pp. 10-11.

19 E. Bryll, Pętla (The Noose), "Orka" 1958, no. 5, p. 6.

20 E. Fleiszer, Konfrontacje. Seria opowiadań na ekranie (Confrontations. A series of short stories on the screen), "Dialog" 1958, no. 3, pp. 125-129.

${ }^{21}$ Cf. Historia filmu polskiego (History of the Polish film), Vol. IV (1957-1961), op. cit., p. 144.

22 A. Tylczyński, Nieprzekonywajaca "Pętla” (Unconvincing “The Noose”), "Tygodnik Demokratyczny” 1958, no. 5, p. 6.

${ }^{23}$ Cf. Historia filmu polskiego (History of the Polish film), op. cit., pp. 140-143.

24 A. Helman, Rok sumuje się doświadczeniami (A year is a sum of experiences), "Ekran” 1958, no. 50/51, pp. 7, 30.

${ }^{25}$ Z. Gawrak, Wyścig z czasem (The race with time), "Stolica" 1958, no. 6, p. 19.

26 P. Kajewski, Na ekranach: "Pętla" (On the screens: "The Noose"), "Odra" 1958, no. 5, p. 2.

${ }^{27}$ Cf. A. Jackiewicz, Dramat antyalkoholowy (An anti-alcohol drama), “Trybuna Ludu” 1958, no. 23, p. 6.

${ }^{28}$ Cf. J. K. Zawistowski, Hłasko w Krainie Czarów (Hłasko in the Wonderland), "Kierunki" 1958, no. 7, pp. 9 and 11. See also a reprint of the Minutes of the Meeting of the Film and Screenplay Evaluation Committee (Protokół z Posiedzenia Komisji Oceny Filmów i Scenariuszy), when the screenplay of The Noose was discussed (6 Nov. 1956). In K. Ludwicki, Kino Marka Hłaski (The cinema of Marek Hłasko), op. cit., pp. 98-116.
} 
literary texts only the theme, the general plot, some of the characters, sometimes the atmosphere in order to create an original work of art.

Nonetheless, most critics appreciated the significant role of The Noose in the Polish cinematography and predicted a bright future for Has. It was noted that in the debut "there is the whole world based on unsettling strangeness, on collisions of time perspectives (...), in which the entire existence is contained" ${ }^{29}$ Juliusz Kydryńki even wrote that it is a work at a European level. ${ }^{30}$ And after some years, during Has's film retrospective in the United States, people did not want to believe that this could be the director's first feature film. ${ }^{31}$

The visual aspect of The Noose, which primarily revealed subjective interests of the director, refers to film expressionism, ${ }^{32}$ and therefore indirectly to expressionist paintings, as well as French films from the so-called black romanticism (e.g., Marcel Carné ${ }^{33}$ ). Moreover, these analogies make the director's debut part of the so-called Polish film school. The esthetics of the latter arose from "the need for stylistic searches, aiming in particular at visualizations and subjectivization of the image of the world (...)".34

The Noose's references to expressionism are confirmed by opinions of critics. ${ }^{35}$ The director himself did not quite agree with such clear analogies. He was afraid of the visual side of the film being associated only with an empty form, which is already dead. He said: "The narration in this film is conducted by means of vivid pictures, it uses the play of symbols, etc., but it does not mean that it is expressionistic straight away". "The director was prepared to agree to such ontology of the visual side of his debut only if one assumes that it is "expressionism filtered through surrealism". ${ }^{37}$ Surreal elements will however be more visible in his later films. Konrad Eberhardt shared those doubts when he wrote that "the possibility of interpretative abuses causes The Noose to be included too directly in the history of cinematography". ${ }^{38}$ It is connected with a tendency to read

${ }^{29}$ See W. Has, Własne skrzydta (Own wings), op. cit., pp. 10-11.

30 J. Kydryński, Hłasko, Has, Holoubek, “Życie Literackie” 1958, no. 5, p. 8.

31 See M. Kornatowska, Artysta $w$ labiryncie świata (An artist in the labyrinth of the world), see http://www.dziennik.com/www/dziennik/kult/archiwum/do-06-00/pp04-28-1.html (date of access: 15 Sep 2015). After some years, already after the adaptation of Anton Czekchov's story, one could read about the surprising connection between The Noose and Nieciekawa historia (Uninteresting story). It was not only about the main character-identical in spiritual terms-played by the same actor Gustaw Holoubek, but also about the theme: approaching death and searching for the "general idea" close to both writers. Marek Hłasko wrote in one of his letters: "Life without an idea is nonsensical, nobody has the right to live without an idea, a life without an idea and faith is a gutter; and all one can do in such a case is die with noise and hatred towards oneself" (quoted after T. Stankiewicz-Podhorecka, Listy Marka Hłaski (Letters of Marek Hłasko), Warszawa 1994, p. 160).

${ }^{32}$ A similar analogy was pointed out in the case of other films by Has, e.g., Wspólny pokój (Common Room). Nonetheless, the atmosphere and the visual side of the screen adaptation of Zbigniew Uniłowski's novel are not as dark as those in The Noose.

${ }_{33}$ When filming The Noose Wojciech Has cooperated with Mieczysław Jahoda, a cinematographer who, according to the director, was at that time "fascinated" by Marcel Carné. That is why in his debut one can notice certain similarities to French films from that period. For example, Carné's best known film Le Quai des brumes (Port of shadows) — which thanks to Trauner's set design and Schufftan's romantic photography came across as grayish and hazy-is close to the pictures of the city in The Noose. Also, the poetic dialogues in the two films: "I see things which are beyond things" (Port of shadows), "life is the worst of dreams" (The Noose), make them similar. Has's attachment to the symbolism of objects (a clock, a telephone, etc.) may also bring associations with films by the French director, especially with Le Jour se lève (Daybreak), in which each memory of the protagonist is triggered by an object. In Daybreak there is also the motif of the protagonist staring into the mirror, which is also characteristic of Has ("listening to oneself", an attempt to investigate the mystery of one's fate). See also A. Helman, Marcel Carné, czyli rzeczywistość upozorowana (Marcel Carné, i.e. simulated reality), "Kino" 1973, no. 8, pp. 62-64.

${ }^{34}$ Cf. A. T. Górski, Jak jest zrobiona "Pętla" Wojciecha Hasa (How is "The Noose" by Wojciech Has made). In Problemy teorii dzieła filmowego (Issues in film theory), J. Trzynadlewski (Ed.), Wrocław 1985, p. 63.

${ }^{35} \mathrm{~K}$. Eberhardt, Pętla - 'swiadomy wybór stylu (The Noose-a conscious choice of style), op. cit., p. 8-14.

${ }^{36}$ W. Has, Nie lubie niespodzianek na planie (I don't like surprises on the set), op. cit., p. 66.

37 Ibid., p. 66.

${ }^{38}$ K. Eberhardt, Pętla-świadomy wybór stylu (The Noose - a conscious choice of style), op. cit., p. 8-14. 
this film through the esthetics of German expressionism. That is why the expressionism of Has's debut should not be perceived superficially, but should be identified primarily with the creation of an autonomous world, parallel to the reality, but created in its entirety by the artist and subjected only to him. ${ }^{39}$ It is about a reality that is defined by concepts such as: visual "density", which is based on dissonance, psychologism, and all-encompassing feeling of pessimism.

\section{Light and Shadow}

In The Noose, light plays a significant role because it has become not only a space-creating element, but also a dramaturgical factor. In this context, we can talk about the visual side of Has's debut being similar to expressionism, which is characterized by sophisticated light effects, reflecting primarily emotional states of presented characters. It was in the expressionist theater and film where lighting was used in a creative manner. ${ }^{40}$

We find a similar way of using light also in The Noose. It is particularly visible in scenes in which daylight sneaks into Kuba's room like luminous snakes crawling out of the gaps between dark curtains or ornaments of glazed doors. It separated the protagonist from the world, creating a kind of intangible bars. A perfect illustration is a scene taking place in the protagonist's apartment, when he talks to a tailor against the backdrop of closed curtains. On the ceiling, one can see beams of light and shadow that spread out radially creating a kind of daggers over Kuba's head or a thorny rosette. In a similar manner, the director shaped one of the final scenes. Here however, we had an additional enhancement of lighting effects with rain trickling down the window pane, which trickles get reflected on the opposite wall and the ceiling creating a kind of a cage.

Interesting in terms of lighting effects is also a scene taking place at the police station. The use of chiaroscuro, which is typical for expressionism, and highlighting the line shadows of the staircase balustrade, cause that the picture can be associated with the respective visions from Robert Wiene's films, e.g., The Cabinet of Dr. Caliari or Crime and Punishment. ${ }^{41}$ The visual play of light and dark lines in The Noose, e.g., the linear ornament on the door, phantasmagoric lamp shapes or vertical stripes on the wallpaper, have a similar effect as sharp contours of objects, curvatures or unsettling vertical and diagonal lines in expressionist painting. As a result of such measures, the feeling of besetment and entrapment in one's fate has got its visual equivalent.

In addition to the possibility of separating the protagonist, light can also signal bonds existing between characters, it can create them or break them off. In The Noose, it is particularly visible when Kuba is seeing Krystyna. At the beginning of the film, we witness a scene of the lovers' embrace, which is very interesting in visual terms. Their apparent closeness is shattered by the expression of the face-mask of Kuba as well as by light which very suggestively shines on the white hair of the woman. The viewer gets the impression that such a procedure, through the contrast: light—dark, in reality serves the purpose of showing the chasm, rather than closeness, between the characters.

\footnotetext{
39 Ibid., pp. 8-14.

40 See e.g., L. H. Eisner, Magia światta. Pótmrok (The magic of light. Dimness). In Ekran demoniczny (Demonic screen), op. cit., pp. 49-63; D. Bablet, Wizja ekspresjonistyczna (Expressionist vision). In Rewolucje scenograficzne w XX wieku (Set design revolutions in the 20th century), translated by Z. Strzelecki, K. Mazur, Warszawa 1980; D. Bablet, Ekspresjonizm na scenie (Expressionism on stage). In Ekspresjonizm w teatrze europejskim (Expressionism in the European theatre), translated by A. Choińska, K. Choiński, compiled by L. Sokól, Warszawa 1983, pp. 126-142; Z. Strzelecki, Współczesna scenografia polska (Contemporary Polish set design), Warszawa 1984; J. Willetta, Ekspresjonizm (Expressionism), translated by M. Kluk, Warszawa 1976.

${ }^{41}$ Ibid., p. 310
} 
The scenes depicting the protagonist's apartment are maintained in half-tone, which is conducive to Rembrandt-like effects. Additionally, the rays of light filtering through closed curtains strike the viewer with their contrasting power. Such a dissonance is typical for expressionist productions in which, especially in the initial period, in order to better highlight the play between light and dark, an additional procedure was used consisting in painting lines on decorations and bodies of actors. Those responsible for the visual side of The Noose did not apply such methods, although they did light the scenes portion by portion, with spots and flashes. In this manner, they created lighting "breaks and refractions", revealed "rigid" relations between the characters and the viewers were subjected to a "play of magical fluctuations". Lotte Eisner noticed that this miraculous power of light, its rhythmical appearance "operates with such an intensity that it appears to resemble sound". ${ }^{2}$ The intention of German directors was to show light and darkness in the very soul of the human being, this constantly recurring transformation of lights and shadows, which characterize the psychological relations between people. ${ }^{43}$ It seems that light which was a "scream" in expressionistic films serves a similar function in The Noose. It has become a physical counterpart of fear, despair, and distress of the protagonist.

The diffusion of light "disappears" only in the culminating moment, when the shaft of light, directed at the protagonist, brutally snatches him out from the surrounding world, causes him to become disillusioned. What is meant here is the most intensively lit part of the film, whose action takes place in the pub "Pod Orkem" ("Under the Eagle"). Light through its sudden "shining" is a metaphorical way of showing illumination, which results in the loss of hope by the protagonist and probably taking the tragic decision about suicide. Here Has, like Wajda, applied the "experiences of painters, especially from the Caravaggio school as well as luminists, on the $a$ rebours basis. In painting, light and white signified positive aspects of the reality, whereas here they clearly stand for lack of hope and defeat" ${ }^{44}$ In the plot of the film this picture is matched with the appearance of Władek - a mirror reflection of Kuba in a few years' time, who makes him aware of the inability to escape one's doomed fate.

Shadow, the opposite of light, dominated in films by expressionists: Robert Wiene, Wilhelm Marnau, or Fritz Lang. It is also the most significant creative and symbolic element in The Noose by Wojciech Has. In primeval beliefs in was a representation of fate, that is why it stayed ahead of the human being and there was no escape from it (Kuba cannot escape his "role" of an alcoholic either). Until today it is considered to be a homeland of the soul or of our dark side. ${ }^{45}$

Wanting to emphasize the bulging contours of objects as well as give shadows sinister and mysterious meaning, expressionists lit a decoration from beneath. Has did a similar thing, although his vision is not that ostentatious, and there are no extreme deformations typical for expressionists either (trapezium-shaped windows, slanting streets, multiplications of the image, etc.). Shadows are supernaturally enlarged, although their sinister, unsettling function has remained. An interesting scene, with a particularly highlighted role of the shadow, is the nighttime walk of the protagonist through the city. It is worth pointing out similarities of this visual image with the relevant pictures of expressionists, whose favorite place of action was a city at night. A good example is a shot from the film The Student of Prague by Henrik Galeen or a work by Ludwik Meidner

${ }^{42}$ L. Eisner, Ekran demoniczny (Demonic screen), op. cit., p. 56.

43 Cf. S. Kracauer, Od Caligariego do Hitlera (From Caligari to Hitler), translated by E. Krzywanowa, W. Wertenstein, Warszawa 1967.

${ }^{44}$ Cf. T. Miczka, Inspiracje plastyczne $w$ twórczości filmowej, telewizyjnej i teatralnej Andrzeja Wajdy (Visual inspirations in film, television and theater works by Andrzej Wajda), op. cit., pp. 40-41.

${ }^{45}$ Cf. W. Kopaliński, Cień (Shadow). In W. Kopaliński, Słownik symboli (Dictionary of symbols), Warszawa 2001, pp. 41-44. 
from the series City. ${ }^{46}$ The light of street lamps glistening on the stone pavement and shadows on buildings extract from this space its hidden and sinister symbolism.

Typical for expressionism was also depicting a figure, or rather its shadow, on glazed surfaces: e.g., doors. This visual motif appears also in the film in question. Several times we see shadows belonging to the tailor or Krystyna, against period, Art Nouveau entrance to Kuba's apartment. They do not fill the viewer with immense fear, but they certainly are ominous for the protagonist, who cannot escape them.

The chiaroscuro in Has's film serves the purpose of concentrating space in oneself. In this way, a narrow, dark, and mysterious world is created. The action usually takes place in-doors or in the city. A grayish afterglow, which additionally intensifies the pessimistic reception of the film, results not only from the will to highlight the atmosphere, emphasize the essence of the content, but from filming on black and white tape. That is why significant is not the color itself, which simply cannot be seen, but quality. It could therefore be claimed that the use of a black and white tape actually helped to bring out the idea of the story. ${ }^{47}$ Thanks to all those procedures lighting in The Noose "is conductive to" the narrowing, the tightening, and the flattening of the field of perception. What is more, it points to a very clear and consistently shaped visual aspect of the film, whose main task is to bring out the essence of its meaning, i.e., showing the inner life of the protagonist-outsider.

\section{Space}

The spatial arrangement in The Noose cannot be identified with an artificial set design built in a film studio, which was a typical for expressionism. On the other hand, the practices of Wilhelm Murnau are close to the director. The former did not create any artificial spaces, but only looked for areas whose natural formation would correspond to the idea of the film. ${ }^{48}$ That is why in Has's debut the city streets are real, the cafe and the pub similar to those that we are familiar with. Dubious is only the appearance of Kuba's apartment, but also in this case we can immediately determine that the protagonist is not an engineer (which is the case in Marek Hłasko's story), but an artist, so such overdone interior decorations (painting tools, empty picture frames on the walls, etc.) could be explained by his profession.

An artificial separation of a portion of a scene (a picture within a picture) should be associated with the appearance of a frame. This, in turn, is characteristic not only of the theater or the motif of characters looking out of a window, which is so common in Wojciech Has's films, but also of paintings. A frame is a kind of a boundary between the external and internal worlds of a picture. "If a painting is constructed taking into account the vantage point of an outsider observer as a "view out of a window"- then the function of a "frame" is to

\footnotetext{
${ }^{46}$ See C. S. Eliel, E. Roters, Ludwig Meidner: Apokaliptische, Landschaften, München 1990.

47 At this point, we can notice a certain similarity with the technique of expressionist painters. Their fascination with color developed into two directions. On the one hand they were attracted to intensive colors, such as red or black. On the other hand, they escaped painting to take up graphic art and wood engraving. Those techniques, in turn, limited the range of colors to white, black, and various shades of grey. Ernst Ludwig Kirchner's claim that graphic art and wood engraving are the only techniques that truly reveal the rank of the artist very well characterized the expressionists. The techniques allow for immersion in the material, for becoming a totality with the work, and by the same token to let it better reflect oneself. The words of E. L. Kirchner are quoted by J. Heynen in Mityzacja procesu tworzenia. Uwagi o roli tworzywa w grafice artystów "Die Brücke" (Mythicization of the creative process. Reflections on the role of the material in graphic art by "Die Brücke" artists). In Grupa "Die Brücke" ("Die Brücke" Group) 1905-1913, exhibition catalogue, Wrocław 1979, p. 13.

${ }^{48}$ Cf. P. A. Kołodyński, Przestrzeń dramatyczna. Uwagi o stylu filmowym Friedricha Wilhelma Murnaua (Dramatic space. Comments on the filmic style of Friedrich Wilhelm Murnau). In Niemiecki ekspresjonizm filmowy (German film expressionism), A. Helman and A. Madej (Eds.), Katowice 1985, pp. 174-186; A. Vidler, The Explosion of Space: Architecture and the Filmic Imaginary. In Film Architecture: Set Designs from Metropolis to Blade Runner, edited by Dietrich Neumann, Munich, London, New Jork 1999, pp. 13-25.
} 
delineate the boundaries of the picture. Meanwhile, if a painting is constructed from the vantage point of an observer set within the presented space - then the "frames" fulfill yet another function: They mean passing from an "external" vantage point to the internal one and vice versa". 49 A frame is therefore a symbolic boundary, separating life from art. That is why any attempts at crossing it may point to a kind of a metamorphosis, that is the transformation of life into art.

An analysis of the spatial arrangement in The Noose: of Kuba's apartment, the pub, and primarily of the city, will become a proof that the "expressionistic" appearance results from a desire to render the essence of the discussed topic. That is why Alicja Helman wrote that,

The Noose by Has - is Kuba's struggle with the world, with life, which took a firm hold of his hands, (...). [And] it takes place outside, at the level of struggling with the matter. The invisible therefore takes on a visual form. ${ }^{50}$

The appearance of Kuba's apartment is an original idea of Has and set designer Roman Wołyniec. In his story, Marek Hłasko does not give any clues as to how the interior should look like. It is therefore an entirely original vision. In the screenplay, we can find the following description:

It used to be an attic, which is suggested by beams under a high ceiling. Through a curtain, which covers one of the walls, daylight filters in, suggesting that there is a large window behind it. On a low table there lie dusted paper rolls, scattered pencils and chisels, bottles of varying sizes, and next to them several sample wood engraving prints. Paintbrushes stick out of pottery vessels, paint tubes lie on a plate; there are a lot of cigarette stubs and ash everywhere. On the walls hang old, empty frames. Adjacent to the studio there is a small room with a window overlooking a street and a courtyard. Through the glass in the entrance door, with a matt, Art Nouveau ornament, one can see the stairs, a long, dark corridor and the entrance to the tailor's apartment. There is a telephone next to the window. ${ }^{51}$

The most important characteristic of the visual arrangement of Kuba's room is the fact that it does not function as a real space, but is a compilation of fragments, each of which is filmed in such a way so that it can serve a specific function. Also for that reason we cannot establish the actual topography. Interiors arranged in such a manner resemble mysterious corridors of a labyrinth. Significant is also the fact that the room and the corridor do not have a clear boundary. They are only separated by glazed doors. It is similar with the window, which separates Kuba's apartment from the courtyard. Paradoxically the closed space of an apartment, which should be a symbol of safety, opens up to undesirable areas: the corridor, the courtyard, and finally the city. The walls, the doors and the mirror-these are visual representations of a very conventional boundary that separates the external reality from Kuba's world of fears and hopes.

Puzzling is also the texture of the apartment walls. It resembles clay surfaces of bizarre buildings from the expressionist film by Henrik Galeen and Paul Wegener entitled Golem, rather than a real, even if badly damaged, interior of a house. In The Noose, like in expressionist films, coarse, devastated walls created a specific atmosphere. The viewer often gets the impression that they give out "the smell of predatory plants, ready to eat people that come near them". That is why flaking plaster is not only a reflection of the psychological state of the protagonist, but it also creates a space with devouring, noxious properties. Instead of protecting Kuba, it brings about his fall. Its stickiness that can be physically felt separates him from the world.

\footnotetext{
${ }^{49}$ B. Uspiański, Struktury wspólne różnych sztuk. Na przykładzie malarstwa i literatury (Common structures of various arts. On the example of painting and literature), translated by Z. Zaron. In Semiotyka kultury (Semiotics of culture), compiled by E. Janus, M. R. Mayenowa, foreword by S. Żółkiewski, Warszawa 1977, pp. 211-242.

${ }_{51}$ A. Helman, Rok sumuje się doświadczeniami (A year is a sum of experiences), "Ekran" 1958, no. 50/51, p. 30.

51 W. Has, Pętla (The Noose)—script, Filmoteka Narodowa, Warszawa S-13969, p. 1.
} 
Intriguing visual elements in this space are also frames. While we could accept such a large collection of paintings, empty frames make us feel uneasy. They may simply be associated with an artist's studio or have a symbolic meaning. Then they would correspond to the inner emptiness of the protagonist, his being burned out, his inability to communicate with others. Similar linear, hollow forms (e.g., window frames) appear in many expressionist performances, for example in sketches to a drama Der Bettler by Reinhard Sorge (1917).

In the studio, there are also scattered paintbrushes and unfinished sculptures. One of them, being a kind of a hollow figure of a person, brings to mind modern art, which after 1956 has begun to develop very quickly in Poland. $^{52}$ It presents a human being, in a defensive posture, trying—like Kuba—to defend himself or separate himself from something.

One more element of the apartment's spatial arrangement remains to be explained, namely, the separation in one of its parts of a platform with stairs and a balustrade. In expressionist films, stairs were primarily to symbolize a human's road to introspection, whereas here they seem to be a threshold similar to a frame. When Kuba passes from the hall to the room that lies lower, he has to cover them. Therefore, he does not climb them, he descends them. It is thus a symbolic passage to the inner space, a kind of an escape from a scene or a foreboding of the protagonist's fall.

Initially Kuba's apartment is his shelter, but the positive nature of this space is "shattered" by the ringing of the telephone. After a while, we can see the "Film" weekly on the floor, on whose cover there is a man smiling impishly (in the script there is information that it is Pickwick ${ }^{53}$ ) with a glass in his hand. In the studio, there are also a lot of bottles of varying sizes, and on the street they are collected by a cleaner. The final scenes, shortly before the suicide of the main protagonist, show how great a metamorphosis this space has undergone. It has become a hostile and dangerous area. For example, Kuba trips on a painting lying on the floor (it is a painting that fits into one of the themes of the film, that of "waiting", i.e., a painting by Edgar Degas called Waiting z $1882^{54}$ ), or unexpectedly discovers a bottle of vodka behind books. ${ }^{55}$

The apartment of The Noose's protagonist may be perceived as a space that encloses him, it both shuts off and opens up, and by the same token it does not protect him against the "enticing" properties of the external world. At the same time, it serves both positive functions (Kuba waits in it for Krystyna) and negative ones (he finds alcohol there). But it can primarily be associated with the protagonist's external world, his "greater body", in which each element is a foreboding and fulfillment of what is to come.

A principal turn of events, i.e., when Kuba becomes aware of his inability to escape his fate, takes place in a pub. Artur Górski noticed that "in the pub "Under the Eagle" Kuba for the first time plays his part, the part of a drunk". 56 The visual arrangement of this space is not that ostentatiously painting-like as the apartment. There is nothing that we would not expect: "A counter, a pool table at the back, tables, pictures of strongmen on walls dark from cigarette smoke (...)" ${ }^{57}$ There are however elements of the interior design that disrupt the order of this space: a stuffed bird hanging under the ceiling, or a notice hung by the waitress: "Exterminate rats". In a sense, they forebode the future of the protagonist. A similar function is served by a character named Władek,

\footnotetext{
52 A. Wojciechowski, Eksplozja nowoczesności 1956-1960 (Explosion of modernity 1956-1960). In Młode malarstwo polskie 1944-1974 (Young Polish painting 1944-1974), Wrocław 1983, pp. 68-92.

53 It should be noted that in 1952 Noel Langley made a film The Pickwick Papers based on Charles Dickens's novel.

54 See e.g., Richard Thomson, Edgar Degas: Waiting, J. Paul Getty Museum, 1995.

${ }_{55}^{56}$ Cf. A. T. Górski, Jak jest zrobiona "Pętla" Wojciecha J. Hasa (How is "The Noose” by Wojciech J. Has made), op. cit., pp. 71, 75.

56 Ibid., p. 74.

57 Cf. A. Jackiewicz, Dramat antyalkoholowy (Anti-alcohol drama), "Trybuna Ludu” 1958, no. 23, p. 6.
} 
who is Kuba's alter ego. He appears behind his back as if a realization of his premonitions. "He is the staging of a play that has been only probable so far, a fiction that has become a reality" 58 Władek, once the best saxophone player in town, will say: "Who drinks will keep drinking. It is a game without a finish line..." 59 In the pub, Kuba also tells his prophetic dream:

I dreamed that each person that I meet on the street says to me: Good morning, drunk. I dreamed that they keep calling me up asking: Hey, how are you doing, got a hangover? Hey, how are you doing, did you booze up last night? (...). I dreamed that I was a drunk. That my name is Kowalski, that there is a phone in my apartment. Do you get it? (...) I dreamed that I wanted to forget about my heavy drinking... To leave the people with whom I have drunk, to leave the pubs, my memories... This is what sometimes happens in a dream, right? (...) But when you are dreaming you cannot escape the dream and this is the worst. ${ }^{60}$

The pessimistic aura of this space is accompanied by some meaningful sounds. In the background, we can hear a song by a blind accordion player:

Dzień jak co dzień, ponury dzień jak co dzień.

Zepsuty zlew, za oknem mgła.

Krople deszczu o brudne biją szyby.

Sąsiad podle na pianinie gra... ${ }^{61}$

A day like any other day, a gloomy day like all the days.

A broken sink, fog behind the window.

Raindrops beat against dirty windowpanes.

The neighbor plays the piano lousily...

The fatalism of Kuba's fate is materialized in this space in the figure of Władek, the dead bird and notices above the counter. It is thanks to those visual aspects that the protagonist experiences a kind of illumination. The space of the pub "Under the Eagle" becomes his self-awareness.

We get to know the city in The Noose both by day and by night. Each time it has nothing in common with a life-throbbing, noisy space. It is surprisingly empty. It rather becomes a devouring, suffocating, and destructive labyrinth. Kuba walks the narrow streets trying to escape the temptation of drinking vodka. Sunlight does not reach this space. Rain does not have a purifying effect. On the one hand the city wraps the protagonist, and on the other it confines him. It has a similar effect like the flaking "sticky" walls of buildings from expressionist films. ${ }^{62}$ Moreover, it has some commonalities with "urban" pictures by Ludwik Meidner or Max Beckmann $^{63}$.

In The Noose, there is a longer sequence in which the protagonist walks around the city. He is then

\footnotetext{
58 A. T. Górski, Jak jest zrobiona "Pętla" Wojciecha J. Hasa (How is "The Noose” by Wojciech J. Has made), op. cit., p. 74.

59 Władek resembles the musician from Zloto (Gold). Moreover, this part is played by the same actor: Tadeusz Fijewski.

${ }^{60}$ W. Has, Pętla (The Noose) - script, op. cit., pp. 130-131. In Jak być kochanq (How to be loved) by Has the protagonist, Wiktor, also dreams about himself.

${ }^{61}$ The song: "Dzień jak co dzień" ("A day like any other day") was one of Marek Hłasko's favorite songs (see W. Has, Nie lubię niespodzianek na planie (I don't like surprises on the set), op. cit., p. 71). Earlier in the café Kuba listens to a song being rehearsed whose words will prove to be ominous: "Miłość ma kolor czerwony/Nucimy ją z gwiazd i bez nut... więc po cóż nam dziś telefony./ Weź nożyczki i odetnij drut..." ("Love has a red color/Let's sing it from the stars and without the score... so why would we need telephones today/Take the scissors and cut off the cable...”). The authors of songs used in The Noose are: A. Benatzky, P. Gerard, S. Karpiński, Z. Marlicz, H. Wars, J. Markowski, J. Petersburski (music); J. Tuwim, K. Winkler, A. Włast, M. Hemar (lyrics).

${ }^{62}$ Cf. A. Kaes, Site of Desire: The Weimar Street Film and D. Neumann, Before and After "Metropolis": Film and Architecture in Search of the Modern City. In Film Architecture: Set Designs from Metropolis to Blade Runner, op. cit., pp. 26-32, 33-38.

${ }^{63}$ See e.g., C. Schulz-Hoffmann, W. Barker, D. Schmidt, Max Beckman: Retrospektive, München 1984.
} 
purposefully filmed in long shot. The director wanted to emphasize the relationship between the urban landscape and the protagonist's emotions. Filming him from a bird's eye view (two shots after his friend's death), somehow "driving" him into the ground, reducing him to the size of a black beetle scurrying down a wide street, the director wanted to show the power of a city that embodies the human fears.

The streets of the city could be an embodiment of Kuba's fate. Maria Malatyńska noticed that in The Noose they are "as drunk as the protagonist". ${ }^{64}$ The wavy lines of the sidewalk have thus the same significance as the pulsating light on the ceiling. They breed fear and exasperation. The image of the city in this film borders on reality and imagination, which is exemplified by: people in rainproof coats, ${ }^{65}$ a small boy in a uhlan paper helmet, coffins propped against a wall, ${ }^{66}$ a neon sign with an ironic slogan Paradise. ${ }^{67}$ Has's city thus turns out to be a tragicomic space. It can also be a kind of a decoration against which a drama of the human loneliness is being staged. In Marek Hłasko's story, the sun comes out after the rain, the wind dries the pavement. Even that one optimistic moment is missing from Has's film.

The vision of the city in The Noose is partly inspired by the appearance of Łódź and Kraków. ${ }^{68}$ It should be noted however that the director does not create an image of some specific city. The action of this film takes place everywhere and nowhere. For that reason, it ceases to be an authentic, reliable background and becomes a representation of the protagonist's mood. A deserted city creates a kind of a private space, which belongs only to Kuba and symbolizes an abyss into which the protagonist has fallen. ${ }^{69}$

\section{Actor and Protagonist}

In The Noose the faces of the characters resemble masks ${ }^{70}$ and it is they that bring out their weaknesses and the feeling of emptiness. ${ }^{71}$ Mieczysław Jahoda, when filming the actors, often did close-ups of their faces, for example, Kuba sitting in the pub "Under the Eagle" over a glass of vodka. Face close-ups can also be associated with looking in the mirror. Usually it is considered that when a person sees themselves in a mirror they lose control over themselves. They give away their life to the picture, divesting themselves of their physicality. They transcend the frame and enter the world of artificial reflections. On the other hand, a face degraded to the function of a component of a picture becomes a visual equivalent of physical death.

An interesting strategy was to dress the protagonist in a Humphrey Bogart-like coat and hat. ${ }^{72}$ Thanks to

\footnotetext{
${ }^{64}$ M. Malatyńska, Twórca uwiedziony literatura (Author seduced by literature), op. cit., pp. 10-17.

${ }^{65}$ Konrad Eberhardt wrote that they resemble characters from the staging of Biesy (Demons) by Andrzej Wajda in Teatr Stary in Kraków (see K. Eberhardt, "Pętla"-Śsiadomy wybór stylu ("The Noose"—a conscious choice of style), op. cit., pp. 12-13).

${ }^{66}$ This visual motif will also appear in e.g., Pismak (Journalist).

${ }^{67}$ Historia filmu polskiego (History of the Polish film), Vol. IV (1957-1961), op. cit., pp. 140-143.

${ }_{68}^{6}$ W. Has, Nie lubie niespodzianek na planie (I don't like surprises on the set), op. cit., pp. 64-69.

${ }^{69}$ Not only the apartment, the city or the pub are spaces that define the protagonist. To this repertoire one should also add the café, in which Kuba meets his former love, the police station, which is interesting because of an original use of chiaroscuro, etc. Nonetheless, it seems that the described spaces are the essence of the director's desire to show the invisible in the material world.

${ }^{70}$ See B. Michałek, W pogoni za stylem (In pursuit of style), op. cit., p. 6.

${ }^{71}$ Cf. J. Pyszny, Bohater $w$ świecie wartości (A protagonist in the world of values). In M. Hłasko, Pierwszy krok w chmurach. Nastepny do raju (The first step in the clouds. The next one to the paradise), op. cit., p. XXIX.

${ }^{72}$ In the context of The Noose's screen adaptation, it is worth noting that the author of The First Step in the Clouds was fascinated with the cinema. For Hłasko film was an escape from everyday life. He was interested in actors such as: Humphrey Bogart, James Dean, etc. Moreover, the writer is an author or co-author of several screenplays: Koniec nocy (End of the night) by P. Komorowski and J. Dziedzina (1957), Skarb kapitana Martensa (The treasure of captain Martens) by J. Passendorfer (1957), Spotkania (Encounters) by S. Lenartowicz (1957), Baza ludzi umartych (A base of dead people) by C. Petelski (1959), Ósmy dzien tygodnia (The eighth day of the week) by A. Ford (1958). See K. Ludwicki, Ksiażka-film: problem adaptacji prozy Hłaski (A book vs. a film: The issue of Hłasko's prose adaptation for the screen). In K. Ludwicki, Kino Marka Htaski (The cinema of Marek Htasko), op. cit., p. 60.
} 
this Kuba began to stand out from the crowd. Like in the case of expressionists, an outfit has become a dramaturgic element. It was to symbolize the protagonist's loneliness and incompatibility with the reality in which he lived. On the other hand it was a kind of a disguise for him, behind which he could hide.

An important role in Kuba's tragedy is played by women. Krystyna is cold, perfect and remote, she belongs to the external world ${ }^{73}$. Wojciech Has claimed that he purposefully chose for this part an actress with a cold appearance, with a flash of cruelty in her eyes ${ }^{74}$. Additionally, her outfit is supposed to emphasize her impersonal coldness, whereas the face is to resemble a dead mask in close-ups. Therefore, the make-up artist and the director deliberately turn Aleksandra Śląska into a person with pale complexion, white hair, nails covered with shiny nail polish, a person which cannot be associated with warmth. She looks more like the demonic Salome or a woman with a zombie-like face from, for example, Oskar Kokoschka's pictures. It should be noted that when she appears (similarly to the tailor), we can hear a jarring sound of the violin, which can additionally stress the that relationship with Kuba is just an appearance. Krystyna saves her lover, but at the same time she besets him and in a way "pushes" to suicide. Contrary to her, the man's former love (Teresa Szmigielówna) is delicate and warm. She can be associated with women from August Macke's paintings. The director wanted her to be a nostalgic memory of something that is lost forever ${ }^{75}$. That is why she belongs to the internal world of Kuba. An interesting role is played by the waitress. According to Dorota Kępczyńska, she is closer to demonic Françoise Rosay than the character she plays (her black outfit is also meaningful) ${ }^{76}$. In a sense she unknowingly serves the role of the oracle (she was being compared to a Sphinx).

The last, but at the same time the "most important woman" in Kuba's life, is a figure painted on the wall. On the one hand she is unattainable because of her being deprived of physicality. On the other hand, she is constantly present, as she appears in the protagonist's most crucial moments of life, especially in the final part of the film, when Kuba sees her through the window almost the whole time. This figure undoubtedly dominated the world of the protagonist. It is her he addresses before death, and not Krystyna's reflection, as was the case in Marek Hłasko's story. She too forebodes his tragedy, she is his doomed fate or simply death ensnaring him as the director claimed ${ }^{77}$.

In Has's film the acting lacks expressionistic ostentation or overdone stylization. In reality it is the decorations, and not the characters, that inform the viewer about the despair, the tragedy, the hopelessness of the situation Kuba has found himself in. Nonetheless the characters of the women, similarly to those of drunks Władek and Rybicki, complement each other perfectly, because in a sense they are projections of the protagonist's internal obsessions.

\section{Mirror and Window}

The synonyms of the lack of love in Kuba's life are props that are particularly highlighted in the film. The

\footnotetext{
${ }^{73}$ Cf. A. Szpulak, Śmierć w polskim filmie fabularnym: od obrazu końca do wizji zmartwychwstania (Death in the Polish feature film: from the image of the end to the vision of resurrection). In Kino polskie wczoraj $i$ dziś. Kino polskie wobec umierania $i$ śmierci (The past and present of the Polish cinema. The Polish cinema vis-à-vis death and dying), P. Zwierzchowski, D. Mazur (Eds.), Bydgoszcz 2005, p. 41.

74 W. Has, Nie lubię niespodzianek na planie (I don't like surprises on the set), op. cit., p. 66.

75 That is why Kuba recites a fragment of a poem by Petrarca Francesco, I know well how cruel a toll (rough translation): I know well how cruel a toll/Death takes, it is never forgiving/How fast we are forgotten/How shortly love despairs over us!(...)

See F. Petrarca, Wybór pism (Selected writings), compiled by K. Morawski, Wrocław 1982, BN II (206).

${ }_{76}$ D. Kępczyńska, Dziecko pijane we mgle (A child in the fog), op. cit., p. 3.

77 W. Has, Nie lubie niespodzianek na planie (I don't like surprises on the set), op. cit., p. 66.
} 
mirror exposes the loneliness and fear of the protagonist. The window separates him from other people, including those who are with him, i.e., women, his former, and present love. The most interesting in visual terms are scenes with the mirror. Mirror reflections, like the play of the shadows, are characteristic of expressionistic art due to its "fascination" with the motif of a lookalike. In The Noose they are particularly important, because - as noted by Artur Górski-"In situations when Krystyna and Kuba become closer emotionally the camera quickly zooms in, so that we can see those situations not in the real space but in the mirror" ${ }^{78}$ In this way, we see a picture within a picture, and the contact between the characters is almost theatrical. The anxiety is also heightened by showing in the mirror a diagonal line of a silhouette of the woman approaching Kuba and a jarring sound of the violin. ${ }^{79}$ The scene brings o mind multi-planar paintings of the leading Polish formist Tytus Czyżewski, e.g., Salome. Such depiction of characters can be associated with symbolic reception of an image as permanent, finite and closed reality, whereas its reflection as a transient and open one, and thus equivocal.

In the final part of the film, when Kuba looks at himself in the mirror, the reflection can be a metaphor of self-knowledge or introspection. It makes him aware that he cannot escape his doomed fate. For Hans Gadamer a reflection is more important that the image itself, as it is associated with the present, with natural experience. ${ }^{80}$ Therefore, it is possible that scenes depicting mirror reflections are more real and tell us more about the protagonists and their loneliness that other filmed images.

\section{Conclusion}

What is also associated with the mirror and a picture within a picture is the motif of looking out of the window so common in Has's films (since then it has been a regular gesture of his protagonists). In The Noose Kuba often looks out at the courtyard or looks at a poster painted on the neighboring building. Also in the last scene the camera is directed at the window from which the protagonist, in fatal convulsions, rips off the curtain. The director reveals the origin of his fascination with this visual motif, writing:

A window is a boundary between two worlds: the internal and external one. That is why my protagonists often look out of a window, sometimes driven by curiosity, sometimes by fear. (...) Here we can see an analogy with the eye of the camera. Through this eye the director looks at the world which he has invented and which he wants to shape. Everything that he sees or shows, he sees and shows through the eye of the camera. This is his window. Transparent and mysterious. ${ }^{81}$

Looking through a glass pane is thus symbolic for Has. On the one hand it is a synonym of seeing and creating a new reality using the lens of a camera, and on the other it symbolizes a boundary between the internal and the external; it is a kind of a "window of the soul", or - as Jan Białostocki wrote - "the light of the body". 82

Kuba, separated from the world by a pane of glass, becomes in a sense separated from the reality. In colloquial language the world behind the glass means apparent accessibility, thus it in fact cannot become fully

\footnotetext{
78 A. Górski, Jak jest zrobiona "Pętla” Wojciecha J. Hasa (How is “The Noose” by Wojciech J. Has made), op. cit., p. 72.

79 It should be mentioned that in paintings death (a skeleton) was often depicted playing the violin, e.g. Arnold Böcklin Self Portrait with Death with a Violin (1872).

${ }^{80}$ H.G. Gadamer, Prawda i metoda. Zarys hermeneutyki filozoficznej (Truth and method), translated into Polish by B. Baran, Kraków 1993, p. 152.

${ }^{81}$ W. Has, Między pamięciq a wyobraźniq (Between memory and imagination), op. cit., pp. 12-14.

82 J. Białostocki, Okno i oko. Realizm i symbolika refleksów światta w sztuce Dürera i jego poprzedników (Window and eye. Realism and symbolism of light reflexes in the art of Dürer and his predecessors). In J. Białostocki, Symbole i obrazy (Symbols and pictures), op. cit., pp. 68-85.
} 
known. It seems that this is also the case with The Noose's protagonist who is aware that looking out of the window is just an empty gesture, only initially giving him illusory hope for escaping himself...from fear and lack of love.

\section{References}

Bablet, D. (1980). Wizja ekspresjonistyczna (Expressionist vision). In Z. Strzelecki and K. Mazur (Trans.), Rewolucje scenograficzne w XX wieku (Set design revolutions in the 20th century). Warszawa: PIW (National Institute of Publishing).

Bablet, D. (1983). Ekspresjonizm na scenie (Expressionism on stage). In Ekspresjonizm w teatrze europejskim (Expressionism in the European theatre) (pp. 126-142). (A. Choińska, K. Choiński, Trans.; compiled by L. Sokół). Warszawa: PIW (National Institute of Publishing).

Białostocki, J. (1986). Okno i oko. Realizm i symbolika refleksów światta w sztuce Dürera i jego poprzedników (Window and eye. Realism and symbolism of light reflexes in the art of Dürer and his predecessors). In J. Białostocki, Symbole i obrazy (Symbols and pictures) (pp. 68-85). Warszawa: PWN (Scientific Publishers).

Bryll, E. (1958). Pętla (The Noose). "Orka", no. 5, p. 6.

Eberhardt, K. (1967). Pętla-świadomy wybór stylu ("The Noose"-a conscious choice of style). In K. Eberhardt, Wojciech Has (pp. 8-14). Warszawa: WaiF (Art and Film).

Eisner, L. H. (2014). Magia światta. Pótmrok (The magic of light. Dimness). In Ekran demoniczny (Demonic screen) (pp. 49-63). Gdańsk: Wydawnictwo Slowo-obraz-terytoria (Word-picture-territories).

Eliel, C. S., \& Roters, E. (1990). Ludwig Meidner: Apokaliptische. Landschaften, München.

Fleiszer, E. (1958). Konfrontacje. Seria opowiadań na ekranie (Confrontations. A series of short stories on the screen). "Dialog", no. 3, pp. 125-129.

Galant, J. (1996). Bogart i inni... (Bogart and others...). In J. Galant, Marek Hłasko. Poznań: "Rebis” Publishing House.

Gadamer, H. G. (1993). Prawda i metoda. Zarys hermeneutyki filozoficznej (Truth and method). (B. Baran, Trans). Kraków: Publishing House: Jagiellonian University.

Gawrak, Z. (1985). Wyścig z czasem (The race with time). "Stolica", no. 6, p. 19.

Górski, A. T. (1985). Jak jest zrobiona "Pętla" Wojciecha Hasa (How is "The Noose" by Wojciech Has made). In J. Trzynadlewski (Ed.), Problemy teorii dzieła filmowego (Issues in film theory). Wrocław: University of Wroclaw.

Has, W. (1998). Nie lubię niespodzianek na planie (I don't like surprises on the set). An interview by M. Kornatowska. In M. Hendrykowski (Ed.), Debiuty polskiego kina (Debuts in the Polish cinema). Konin: Publishing House: "Konin Overview".

Has, W. ( 1955-1956 ). Pętla (The Noose)—script, Filmoteka Narodowa. Warszawa S-13969, p. 1.

Helman, A. (1958). Rok sumuje się doświadczeniami (A year is a sum of experiences). "Ekran”, no. 50/51, pp. 7, 30.

Helman, A. (1973). Marcel Carné, czyli rzeczywistość upozorowana (Marcel Carné, i.e. simulated reality). "Kino”, no. 8, pp. 62-64.

Helman, A. (1958). Rok sumuje się doświadczeniami (A year is a sum of experiences). "Ekran”, no. 50/51, p. 36.

Heynen, J. (1979). Mityzacja procesu tworzenia. Uwagi o roli tworzywa w grafice artystów "Die Brücke" (Mythicization of the creative process). Reflections on the role of the material in graphic art by "Die Brücke" artists. In Grupa "Die Brücke" ("Die Brücke" Group), 1905-1913, exhibition catalogue. Wrocław: National Museum in Wroclaw.

Historia filmu polskiego (History of the Polish film). Jerzy Toeplitz (Ed.), Vol. IV (1957-1961). Warszawa: WaiF (Art and Film).

Jackiewicz, A. (1958). Dramat antyalkoholowy (An anti-alcohol drama). "Trybuna Ludu”, no. 23, p. 6.

Jarzębski, J. (1984). Powieść jako autokreacja (A novel as self-creation). Kraków: Literary Publishing.

Kajewski, P. (1958). Na ekranach: "Pętla" (On the screens: "The Noose"). "Odra", no. 5, p. 2.

Kaes, A. (1999). Site of desire: The Weimar Street Film and D. Neumann, before and after "Metropolis": Film and architecture in search of the Modern City. In Film architecture: Set designs from Metropolis to Blade Runner (pp. 26-32, 33-38). Retrieved X 24, 2015 from http://www.amazon.com/Film-Architecture-Metropolis-Blade-Runner/dp/3791321633

Kołodyński, P. A. (1985). Przestrzeń dramatyczna. Uwagi o stylu filmowym Friedricha Wilhelma Murnaua (Dramatic space. Comments on the filmic style of Friedrich Wilhelm Murnau). In A. Helman and A. Madej (Eds.), Niemiecki ekspresjonizm filmowy (German film expressionism) (pp. 174-186). Katowice: University of Katowice/ Silesian University.

Kopaliński, W. (2001). Cień (Shadow). In W. Kopaliński, Stownik symboli (Dictionary of symbols) (pp. 41-44). Warszawa: PWN (Scientific Publishers). 
Kornatowska, M. (2000). Artysta $w$ labiryncie świata (An artist in the labyrinth of the world). Retrieved from http://www.dziennik.com/www/dziennik/kult/archiwum/do-06-00/pp04-28-1.html

Kracauer, S. (2009). Od Caligariego do Hitlera (From Caligari to Hitler). (E. Krzywanowa \& W. Wertenstein, Trans). Gdańsk: Wydawnictwo Slowo-obraz-terytoria (Word-picture-territories).

Kuśmierczyk, S. (2000). Wstęga Möbiusa jako czasoprzestrzeń dzieła filmowego. Na przykładzie "Pętli” Wojciecha Hasa i "Zabicia ciotki" Grzegorza Królikiewicza (The Möbius strip as the space-time of a filmic work. On the example of "The Noose" by Wojciech Has and "The Killing of the Aunt" by Grzegorz Królikiewicz). "Kwartalnik Filmowy", no. 29/30, pp. 20-30.

Kydryński, J. (1958). Hłasko, Has, Holoubek. “Życie Literackie”, no. 5, p. 8.

Ludwicki, K. (2004). Marek Hłasko-pozer czy outsider? (Marek Hłasko-poser or outsider?). In K. Ludwicki, Kino Marka Hłaski (The cinema of Marek Hłasko). Katowice-Warszawa: University of Katowice/Silesian University.

Marszałek, R. (1973). Tubylec i misjonarze (A native and missionaries). "Kino", no. 3, pp. 23-24.

Michałek, B. (1958). W pogoni za stylem (In pursuit of style). "Nowa Kultura", no. 6, p. 6.

Michałek, B. (1958). Nadzieje, niepokoje (Hopes and fears). "Teatr i Film", no. 4, pp. 10-11.

Michałek, B. (1960). Szkice o filmie polskim (Sketches on the Polish film). Warszawa: WaiF (Art and Film).

Miczka, T. (1988). Inspiracje plastyczne w twórczości filmowej, telewizyjnej i teatralnej Andrzeja Wajdy (Visual inspirations in film, television and theater works by Andrzej Wajda) (pp. 40-41). Katowice: University of Katowice/ Silesian University.

Petrarca, F. (1982). Wybór pism (Selected writings). (compiled by K. Morawski). Wrocław: The National Library, BN II (206).

Pyszny, J. (1999). Przestrzeń (Space). In M. Htasko, Pierwszy krok w chmurach. Następny do raju (The first step in the clouds. The next one to the paradise). (compiled by J. Pyszny). Wrocław: The National Library, BN I 295, pp. XXIX-XXXV.

Roszko, J. (1967). Cudowna podróż po rynsztokach świata (An amazing journey to the gutters of the world). "Dziennik Polski", no. 167.

Schulz-Hoffmann, C., Barker, W., \& Schmidt, D. (1984). Max Beckman: Retrospektive. München: Prestel Publishing.

Skwara, J. (1977). Świat "czarnego filmu" (The world of "black film"). Warszawa: Publishing House "Book and Knowledge".

Stabro, S. (1983-1984). W bursztynowej kuli. O twórczości i legendzie Marka Hłaski (In an amber ball. On the work and legend of Marek Hłasko). "Odra", 1983, no. 12 and 1984, no. 1.

Strzelecki, Z. (1976). Współczesna scenografia polska (Contemporary Polish set design). Warszawa 1984; J. Willetta Ekspresjonizm (Expressionism). (M. Kluk, Trans.). Warszawa: WaiF (Art and Film).

Szpulak, A. (2005). Śmierć w polskim filmie fabularnym: od obrazu końca do wizji zmartwychwstania (Death in the Polish feature film: from the image of the end to the vision of resurrection). In P. Zwierzchowski and D. Mazur (Eds.), Kino polskie wczoraj $i$ dziś. Kino polskie wobec umierania i śmierci (The past and present of the Polish cinema. The Polish cinema vis-à-vis death and dying). Bydgoszcz: University of Bydgoszcz.

Thomson, R. (1995). Edgar Degas: Waiting. Malibu: J. Paul Getty Museum.

Tomkowski, J. (1995). Marek Hłasko jako bajkopisarz (Marek Hłasko as a fabler). In A. Brodzkiej and L. Burskiej (Eds.), Sporne postaci polskiej literatury wspótczesnej (Disputed figures in the contemporary Polish literature). Warszawa: Institute of Literary Research PAN.

Tylczyński, A. (1958). Nieprzekonywajaca "Pętla” (Unconvincing “The Noose”). "Tygodnik Demokratyczny”, no. 5, p. 6.

Uspiański, B. (1977). Struktury wspólne różnych sztuk. Na przykładzie malarstwa i literatury (Common structures of various arts. On the example of painting and literature). In Semiotyka kultury (Semiotics of culture) (pp. 211-242). (Z. Zaron, Trans.; compiled by E. Janus \& M. R. Mayenowa; foreword by S. Żółkiewski). Warszawa: PWN (Scientific Publishers).

Wasilewski, P. (1994). Śladami Marka Hłaski (In the footsteps of Marek Hłasko). Kraków: Publishing House "Parol".

Wojciechowski, A. (1983). Eksplozja nowoczesności 1956-1960 (Explosion of modernity 1956-1960). In Młode malarstwo polskie 1944-1974 (Young Polish painting 1944-1974) (pp. 68-92). Wrocław: “Ossolineum".

Vidler, A. (1999). The explosion of space: Architecture and the filmic imaginary. In D. Neumann (Eds.), Film architecture: Set designs from Metropolis to Blade Runner (pp. 13-25). Munich, London, New York: Prestel Publishing.

Zaleski, K. (1974). Inferno sentymentalne (Sentimental inferno). "Teksty”, no. 2.

Zawistowski, J. K. (1958). Hłasko w Krainie Czarów (Hłasko in the Wonderland). “Kierunki”, no. 7, pp. 9, 11. 